\title{
Interfaces
}

INTERFACES Image Texte Language

$46 \mid 2021$

Jeux de Formats (2)

\section{The Lehman Trilogy : Is there a point?}

\section{Donald Friedman}

\section{(2) OpenEdition}

\section{Journals}

Electronic version

URL: https://journals.openedition.org/interfaces/4124

DOI: 10.4000/interfaces.4124

ISSN: 2647-6754

\section{Publisher:}

Université de Bourgogne, Université de Paris, College of the Holy Cross

\section{Electronic reference}

Donald Friedman, "The Lehman Trilogy: Is there a point?", Interfaces [Online], 46 | 2021, Online since 15 December 2021, connection on 17 June 2022. URL: http://journals.openedition.org/interfaces/4124 ; DOI: https://doi.org/10.4000/interfaces.4124

This text was automatically generated on 17 June 2022.

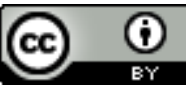

Les contenus de la revue Interfaces sont mis à disposition selon les termes de la Licence Creative Commons Attribution 4.0 International. 


\title{
The Lehman Trilogy : Is there a point?
}

\author{
Donald Friedman
}

\author{
Stefano Massini, The Lehman Trilogy. Adapted by \\ Ben Power, directed by Sam Mendes, Nederlander \\ Theatre, 208 W 41st ST. New York, NY 10036.
}

1 I repeatedly tried and failed to get a ticket to The Lehman Trilogy when it was mounted at New York's Armory and, despairing, would have settled for a streamed version, but couldn't match the odd venues and times with my own. So I jumped at tickets on its return to Broadway, even before Covid was (more or less) under control here, and finally got to experience it live the other night.

It was quite an experience. Simon Russell Beale, whom I'd thrilled to as Hamlet and Uncle Vanya and Malvolio, among other challenging roles, and who is among the world's greatest living stage actors, did not disappoint as Henry Lehman, and found his equals in Adam Godley and Adrian Lester as his brothers. In bravura performances the three are not only the brothers, but, with sudden small alterations in voice or posture, become their customers, colleagues and competitors, their loves, spouses, children and the generations of Lehmans who succeeded them.

3 The brilliantly conceived, stripped down set consisted of only a rotating glass-walled conference room behind which was a curved screen on which were projected every image needed to convincingly place scenes in their historic and geographic contexts, from fields of burning cotton in Alabama to New York City through the decades. The projections were to some degree surplusage; in the Shakespearean mode, the play localizes through its dialogue. And although visuals, as every marketeer and entertainer knows, are processed exponentially faster than text, words give access to the imagination and are more generative. The playwrights also telescope time, as Strindberg did in The Ghost Sonata, where a lifetime is experienced in an hour, but do him one better, compressing nearly two centuries into an evening. A large supply of prop boxes were stacked by the actors to create whatever was required in the moment -from store counter to living room couches and chairs. All plaudits to director Sam Mendes and his team for this slick, well-paced entertainment. 
But, I wondered as I walked out, what did I miss? Not only did I not get any kind of message, no moral, or instructive truth - there were no ethical questions to contemplate, not even the obvious one of whether we should see the brothers' profiting from slave-produced cotton as making them complicit. (Of course, slavery was the base of the nation's economy, cotton its number one export, and the North happily pocketed slavers' cash for its manufactured goods. Famed abolitionist William Lloyd Garrison, accurately denounced the North as the South's "partner in iniquity.") This could have been rather easily done since the play uses a hybrid kind of story theater structure; the story is not simply told in dialogue, but is narrated in the third person - the actor providing backstory and setting, and describing his character's behavior even as he's inhabiting him or her.

5 And although I followed the Lehmans' struggles and triumphs as they grew their business from the little dry goods store Henry opened in Montgomery, Alabama in 1844 , to become cotton and coffee traders and railroad financers, survived the Civil War and the industrialization of the country, and the crash of 1929, and The Depression, etcetera, the essential story seemed to elude me; the drama had little drama in it. A couple of days of reflection only reinforced that view. The author, Stefano Messini, scripted the original version in Italian as a five-hour history ostensibly of the rise and fall of the illustrious family over 163 years - and Ben Power adapted it as a three-hour English version. Both saw a clear narrative arc from the immigrant brothers' humble beginnings selling sundries from their rural store, to their ingenious reinvention as "middlemen," to the collapse of the humongous Lehman bank in 2008 when its failure arguably set off the world's financial crisis.

6 The problem for me is that the story of the Lehman immigrants is not a unique one but part of a larger one not addressed; their story is one shared by any number of Jewish immigrants from 19th century Germany. By 1845 seventy percent of the Jewish men in America earned their livings as peddlers - walking with 100-plus pound packs on their backs until they saved enough to buy a horse and wagon. They migrated to agricultural areas, not to farm but to offer finished goods to people who had no access to stores. Marcus Goldman, founder of Goldman Sachs, emigrated from Bavaria about the same time as the Lehmans, was a peddler with a horse-drawn cart before setting himself up as a middleman, brokering IOUs and then commercial paper. Alexandre Lazard and his two brothers, had a dry goods store in New Orleans before they were Lazard Freres, brokering gold between San Francisco and Europe, during the gold rush. The German Jews - Levi Strauss (who had a dry goods store with his brothers before heading west to sell denim to the miners), Benjamin Bloomingdale, Meyer Guggenheim, Adolph Sutro, the Kuhns and Loebs and Schiffs - all founders of great businesses and dynastic families were fleeing poverty and oppression - especially the rules that forbade more than a certain number of Jews to marry and then only if deemed to be economically qualified.

7 The Lehman brothers' supposed reinvention of themselves as middlemen, was, in fact, a role that was not only not original with them, as the play insists, but was assumed by (and frequently imposed upon) Jews for many centuries throughout Europe. Jews were not permitted to own land, or to join guilds, and they became traders and money lenders, the latter a forbidden occupation for Christians and conveniently allowed the ruling classes to use the Jews to soak up money from the peasantry and then steal it from them. 
Perhaps most undermining of the Lehman boom and eventual bust narrative, no Lehman family member had been active in the investment banking firm for forty years before its collapse-Robert Lehman was the last, his tenure ending with his death in 1969. Pete Peterson who took over, merged the firm with Kuhn, Loeb, and then solved an internal feud with Lewis Glucksman by making him co-CEO, and when that didn't work out, left Glucksman in charge and, by 1984, he was forced to sell the place to Shearson/American Express for $\$ 360$ million. Then it was merged with E.F. Hutton and eventually spun off and managed by Richard Fuld. Numerous acquisitions followed and the firm was then built with some questionable behavior (letting the investment bankers control their analysts for which the SEC assessed an $\$ 80$ million penalty and imposed structural reforms) and ultimately very bad lending decisions-creating a hugely overvalued portfolio ( $\$ 680$ billion in questionable real estate) supported by $\$ 22$ billion in capital so that even a three percent drop in real estate value would wipe out their capital.

9 So, what do we learn from the Lehman Brothers' Trilogy? Easier to say what we don't learn, viz: we learn nothing of the economic chaos and antisemitic evils in Germany that sent the brothers to rural America. We learn nothing about the brothers' relationship to the slaves who were the engine of the economy supporting their business-not even whether they were selling to the slaves (many Jewish peddlers did) as well as to the slavers-not even whether they had a judgment about it. We learn nothing about whatever antisemitism they encountered in their dealings either in the South or the North. We learn only parenthetically of family estrangements, and nothing of the advantageous marriages they made with powerful families - the Morgenthau, Bronfman, Loeb, Weill, Hirschhorn, Altshul families. We learn nothing of the Lehman resources today, of their philanthropy. As for the collapse of Lehman Brothers, the reasons behind it - the story of the sub-prime mortgage fiasco - and the last days of the business, have been well-dramatized by others on stage and in film.

What we do learn, however, is that the Jews who landed here saw not only the boundless opportunities that every kind of arriving refugee sees, but how to apply the survival lessons learned through the centuries of oppression, of exclusion, of being forced to work as middlemen, to deal in abstractions like the time-value of money, implicit in lending and expressed in the credit instruments that are the essence of banking and which Jewish spice traders had been using as they followed the global routes in the early Middle Ages long before the first banks even existed.

11 In this sense, the story of the Lehmans is a different kind of American creation myth; while the revered founders of the country - Washington, Jefferson, Madison, Monroe were planters and, not incidentally, slave owners, it fell to the Polish-born Jew, the middleman broker and financier, Haym Solomon, to finance their Revolution and then to advise Hamilton on how to create a federal bank. The entrepreneurship of the Lehmans, and their German Jewish cohort, gives the lie to Max Weber's claim that Protestantism underpins our economies and his blind, antisemitic insistence that Jews offer nothing but "pariah capitalism."

12 We also learn how a minimalist set and three brilliant actors can transcend the material, keep you enthralled and bring you to your feet at the end of three and half hours. 


\section{AUTHOR}

\section{DONALD FRIEDMAN}

Donald Friedman, a novelist, essayist, sometime lawyer, but never a scholar, somehow produced the internationally acclaimed The Writer's Brush: Paintings, Drawings, and Sculpture by Writers. That book brought together the visual art of more than 200 of the world's great writers. To celebrate its publication, he planned a modest exhibition of writer-art which, with the assistance of John Wronoski, antiquarian bookseller and art dealer, was enlarged to include dozens of poets and writers somehow omitted from the book, and became a museum-scale show (https:// donaldfriedman.com/books/the-writers-brush-the-exhibition/). Along the way to the book and the exhibition, Friedman interviewed a number of writer-artists on camera. Excerpts of those interviews are being posted on Interfaces' website, accompanied by transcripts and introductions. For Interfaces contributors and friends interested in acquiring copies of The Writer's Brush direct from the author at a deep discount, please contact him through his website, https://donaldfriedman.com/books/the-writers-brush/ 